\title{
Geociênciacias
}

\section{The pyroclastic dyke and welded crystal tuff of the Morro dos Gatos alkaline intrusive complex, State of Rio de Janeiro, Brazil}

\author{
Dique piroclástico e tufo soldado com alto teor de \\ cristais do complexo intrusivo de rochas alcalinas \\ do Morro dos Gatos, RJ
}

\begin{abstract}
Akihisa Motoki
Departamento de Mineralogia e Petrologia Ígnea, Universidade do Estado do Rio de Janeiro rochasornamentais@yahoo.com.br

Mauro Cesar Geraldes

Departamento de Geologia Regional,

Universidade do Estado do Rio de Janeiro geraldes@uerj.br
\end{abstract}

\section{Woldemar Iwanuch \\ Departamento de Mineralogia e Petrologia Ígnea, Universidade do Estado do Rio de Janeiro nefelinasienito@yahoo.com.br}

\section{Thais Vargas}

Departamento de Mineralogia e Petrologia Ígnea, Universidade do Estado do Rio de Janeiro thaisvargasuerj@gmail.com

\section{Kenji Freire Motoki}

Departamento de Geologia,

Universidade Federal Fluminense

kenji_dl@hotmail.com

\begin{abstract}
Alex Balmant
Departamento de Mineralogia e Petrologia Ígnea, Universidade do Estado do Rio de Janeiro alexbalmant@yahoo.com.br
\end{abstract}

\section{Marina Nascimento Ramos}

Departamento de Mineralogia e Petrologia Ígnea, Universidade do Estado do Rio de Janeiro marinanascimentoramos@hotmail.com

\section{Resumo}

O presente artigo relata as características geológicas, litológicas e petrográficas do dique piroclástico e tufo soldado intrusivo com alto teor de fenocristais e fragmentos de minerais do complexo intrusivo de rochas alcalinas do Morro dos Gatos, RJ.

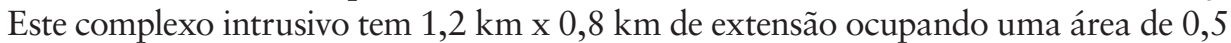
$\mathrm{km}^{2}$, e é constituído, principalmente, por monzonito e traquito. $\mathrm{Na}$ encosta sul do morro, ocorre um dique composto de rocha piroclástica e, na encosta noroeste, tufo soldado intrusivo com alto teor de fenocristais e fragmentos de minerais. $\mathrm{O}$ dique piroclástico é de 40 a $80 \mathrm{~cm}$ de largura, é intrusivo no granito porfirítico do embasamento e é constituído por tufo-brecha fortemente soldado, que contém fragmentos angulosos de traquito de tamanho de lapilli. Ao longo do plano de contato do dique piroclástico, ocorre a intercalação do traquito. Por outro lado, o tufo soldado é caracterizado por abundância de fenocristais de feldspato alcalino e fragmentos de minerais de feldspato alcalino, quartzo, biotita, anfibólio e fragmentos líticos de traquito, apresentando textura suportada por cristais e matriz. Os fenocristais grandes são os agregados compostos de feldspato alcalino idiomórfico com o tamanho geral de $2 \mathrm{~mm}$, no máximo de 6 $\mathrm{mm}$. A matriz é constituída, principalmente, por fragmentos de minerais de tamanho geral menor do que $1 \mathrm{~mm}$. O diagrama de distribuição entre o tamanho e a frequência, para os fragmentos, sugere que estes foram originados de uma erupção explosiva. A matriz é fortemente soldada e completamente devitrificada, apresentando textura criptocristalina. Os cristais foram concentrados pela seleção granulométrica por gás vulcânico em ascensão no conduto subvulcânico durante a fase de erupção contínua e efusiva. A distribuição espacial limitada das rochas piroclásticas e o tamanho pequeno do afloramento, indicam que essas não são constituintes de fluxo piroclástico, mas de conduto e fissura subvulcânicos.

Palavras-chave: Morro dos Gatos, dique piroclástico, tufo soldado, conduto subvulcânico, fissura subvulcânica, rocha alcalina.

\section{Abstract \\ The present article reports the geologic, lithologic, and petrographic characteris- tics of the pyroclastic dyke and phenocryst-rich welded crystal tuff of the Morro dos Gatos alkaline intrusive body, State of Rio de Janeiro, Brazil. The intrusive complex has an extension of $1.2 \times 0.8 \mathrm{~km}$ occupying an area of $0.5 \mathrm{~km}^{2}$. It is constituted main- ly by monzonite and trachyte. At the south flank of the massif, there exits a pyroclastic}


dyke and at the northwest flank, an intrusive welded crystal tuff. The pyroclastic dyke is 40 to $80 \mathrm{~cm}$ wide and intrudes into the basement porphyritic granite. This rock is constituted by welded tuff breccia with large amount of lapilli-size angular lithic fragments of trachyte. Along the contact plane of this dyke, there is an intercalation of the trachyte. The crystal tuff is characterised by abundant alkaline feldspar phenocrysts and mineral fragments of alkaline feldspar, quartz, biotite, and amphibole, showing a crystal matrix-supported texture. Large phenocrysts are aggregations of idiomorphic alkaline feldspar crystals with a general size of $2 \mathrm{~mm}$ and a maximum one of $6 \mathrm{~mm}$. The matrix is composed mainly of mineral fragments of less than $1 \mathrm{~mm}$ in general size. The size-frequency diagram for the mineral fragments suggests that they have been originated from an explosive eruption. The matrix is strongly welded and completely devitrified showing a cryptocrystalline texture. The crystals were concentrated by sorting with the help of the volcanic gas ascending in the volcanic conduit during a continuous and effusive phase of the eruption. The limited special distribution of the pyroclastic rocks and small outcrop size indicate that they are not constituent of pyroclastic flow deposits, but of subvolcanic conduit and fissure.

Keywords: Morro dos Gatos, pyroclastic dyke, welded tuff, subvolcanic conduit, subvolcanic fissure, alkaline rock.

\section{Introduction}

Welded tuff generally occurs as a hot and thick pyroclastic flow deposit (e.g. Smith, 1960; MacDonald, 1972). In some cases, glass shards can be fused and the matrix transforms into massive hot glass, showing similar physical behaviours of viscous lava flows. The rock is characterised macroscopically by flattened essential fragments called essential lens or fiamme. The above-mentioned volcanic deposits are emplaced on the Earth's surface forming extrusive rock bodies. Therefore, many authors consider pyroclastic rocks and welded tuff directly and unconditionally as a constituent of a pyroclastic flow deposit of extrusive eruptive materials.

On the other hand, welded tuffs

\section{Regional geology}

The regional continental basement around the Morro dos Gatos body is constituted by paragneiss of the Costeiro Unit, orthogneiss of the Oriental Terrane, and post-tectonic granite of the Pan-African continental collision event (Heilbron et al., 2000; Heilbron \& Machado, 2003). They are cut by the tectonic breccia of the last phase of this orogeny (Motoki et al., 2011). All of them are intruded by the early Cretaceous mafic dykes related to the continental flood basalt of the Paraná Province (Guedes et al., 2005; Motoki et al., 2009a). also occur in forms of intrusive bodies such as subvolcanic conduits, subvolcanic fissures, and pyroclastic dykes (e.g. Ekren, \& Byer, 1976; Motoki, 1979; Reedman et al., 1987; Kano et al., 1996; Wolff et al., 1999). In Brazil, the examples have been reported in the felsic alkaline bodies, such as those of Mendanha (Mota \& Geraldes, 2006; Motoki et al., 2007a; Alves et al., 2011; Mota et al., 2011), Itaúna (Motoki et al, 2008a), Cabo Frio Island (Sichel et al., 2008), and Tunas (Vasconcellos \& Gomes, 1992). Among them, the pyroclastic rock of the Itaúna body presents a relevant eutaxitic texture (Motoki et al., 2008b). The intrusive pyroclastic rocks show extremely strong welding (Motoki,
1979; Motoki \& Sichel, 2006) and essential lenses become imperceptible because of the highly developed deformation by the secondary flowage. They are little known and only a small number of research papers are available.

Recently, the authors have found a new example of a pyroclastic dyke composed of welded tuff breccia and phenocryst-rich welded crystal tuff in the alkaline intrusive rock body of Morro dos Gatos, State of Rio de Janeiro, Brazil. The present paper reports the field description, lithologic annotation, and petrographic observation of the pyroclastic dyke and intrusive welded crystal tuff. Based on these observations, the authors consider the formation process.

\section{Morro dos Gatos alkaline intrusive body}

The Morro dos Gatos hill, whose name means "Cats' Hill", is situated at the coordinates of $22^{\circ} 37.7^{\prime} \mathrm{S}, 42^{\circ} 29.0^{\prime} \mathrm{W}$ 
in the central region of the State of Rio de Janeiro. It is located along Federal Freeway BR-101, about $83 \mathrm{~km}$ to the east-northeast of the Rio de Janeiro City, $10 \mathrm{~km}$ to the west-northwest of Silva Jardim, $1.5 \mathrm{~km}$ to the north of Cesário Alvim, and 1.5 $\mathrm{km}$ to the south of Imbaú (Figure 2). This alkaline rock was reported by Martins \& Borghi (1982).

Figure 1

Alkaline rock bodies of the State of Rio de Janeiro, Brazil, indicating the Morro dos Gatos alkaline intrusive rock body, modified from Motoki et al.

(2010; 2011).

elevations from 300 to $900 \mathrm{~m}$ in relative height. However in case of the Morro dos Gatos, this phenomenon is not relevant because of the limited distribution area of the alkaline rocks.

Most of the parts of the hill expose boulders of porphyritic granite of Silva Jardim. This granite is the country rock of the alkaline intrusive body and intruded during the Pan-African continental event, with the U-Pb age of $505 \pm 2 \mathrm{Ma}$ (Moraes, 2009). It is characterised by abundant alkaline feldspar phenocrysts of centimetres in size showing a cumulative texture.

The Morro dos Gatos alkaline intrusive rock body is considered to be a member of the late Cretaceous to early Cenozoic felsic alkaline magmatism suit of the Poços de Caldas - Cabo Frio. Its intrusive age is estimated to be about 65 $\mathrm{Ma}$, according to the $\mathrm{Rb}-\mathrm{Sr}$ age of the adjacent alkaline intrusion of Tanguá (Motoki et al., 2010).

Figure 2

Locality map showing access to the Morro dos Gatos alkaline intrusive rock body. The satellite image is originated from Google Earth ${ }^{\mathrm{TM}}$. The alkaline rock distribution area is calculated by digital image analyses with the help of the software Wilbur 1.0 (Motoki et al., 2005; 2006) according to the method of Motoki et al. (2007c; 2009b). Tr - first generation trachyte; Mz - monzonite; Gr - Silva Jardim Granite.
Morphologically, the Morro dos Gatos hill is $3 \mathrm{~km}$ long in a ENE-SWS direction, $1 \mathrm{~km}$ wide, and $280 \mathrm{high}$. According to the geologic map of the Brazilian Geological Survey (Companhia de Pesquisa de Recursos Minerais - Serviço Geológico do Brasil, CPRM), the distribution area of the alkaline rocks was estimated to be $5 \mathrm{~km}^{2}$ (Silva L.C. et al.,
2000). However, the recent fieldworks have revealed that the alkaline rocks are present only at the western border of the hill and its distribution area is, in fact, only $0.5 \mathrm{~km}^{2}$. Due to the erosive resistance of alkaline syenite and nepheline syenite under the weathering passivity effects (Motoki et al., 2008d; Silva S., 2010), the alkaline intrusive bodies form topographic

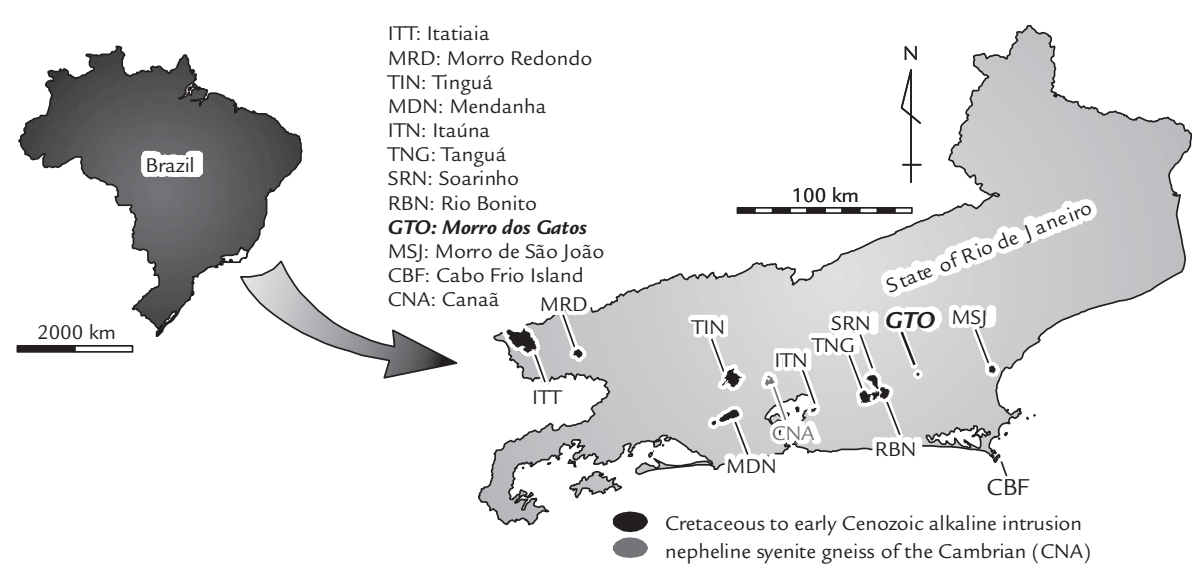

A half of the Morro dos Gatos hill is covered by dense forest and another half by low bush exposing boulders up to $8 \mathrm{~m}$ in size in some localities. The outcrops are very limited being observed only at two sites. Therefore, high-resolution geologic mapping is not available.

This intrusive complex is made up mainly of equigranular monzonite (field name) with a very little amount of quartz and porphyritic trachyte with holocrystalline groundmass. The grain size of monzonite varies from 2 to $3 \mathrm{~mm}$. No mineral orientation is observed. Plagioclase is present, forming a core of phenocrystlike feldspar crystals and a framework of interstitial texture. According to the classification nomenclature of Streckeisen (1973), this rock is plotted on the limit between the syenite of field 7 and the monzonite of field 8 . The mafic minerals are biotite and light-green clinopyroxene. Optically, they seem to be aegirine-augite or dipopside. The modal content of the mafic minerals is about $30 \%$. There is a notable abundance of apatite with a size of $0.1 \mathrm{~mm} \times 0.4 \mathrm{~mm}$.

The holocrystalline porphyritic trachyte occurs massively on the northwestern slope of the hill. This locality corresponds to the northwest border of the intrusive body. The rock has large and abundant almost cubic alkaline feldspar phenocrysts with a typical size of 3 $\mathrm{mm}$ to $5 \mathrm{~mm}$. The groundmass is holocrystalline and relatively gross-grained with alkaline feldspar crystals of $0.1 \mathrm{~mm}$ x $0.4 \mathrm{~mm}$ with a slight orientation. The groundmass texture and the discontinuous field distribution indicate that this trachyte is not a constituent of extrusive bodies, such as lava flow and lava dome, but of an intrusive body. The intrusive trachyte with a similar mode of occurrence and a similar texture is known in the Mendanha felsic alkaline body

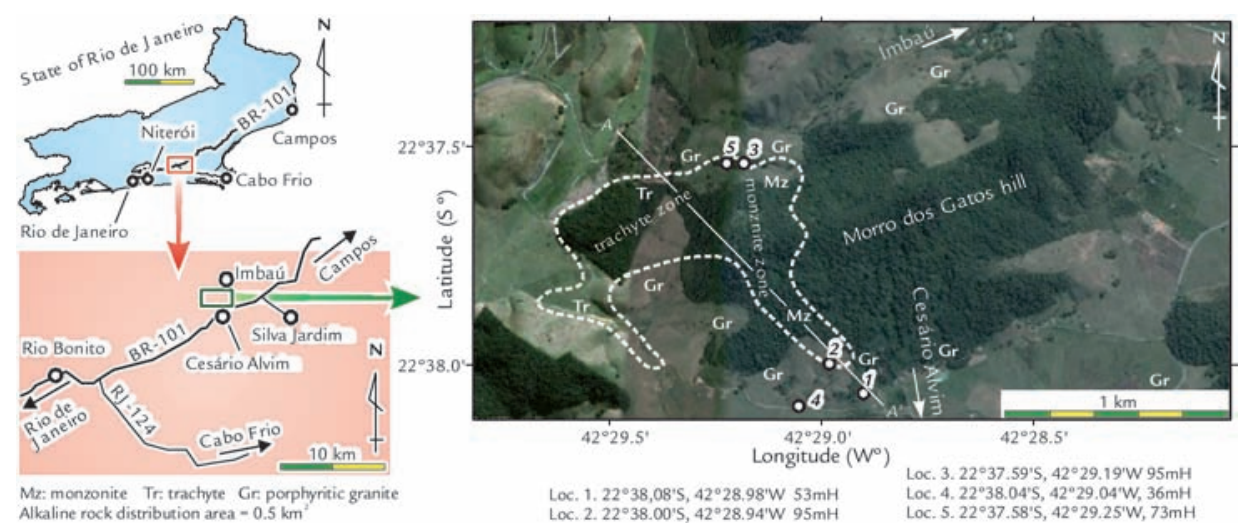


(Motoki et al., 2007b). The trachyte intrusion took place before the syenite, and therefore, it is called the first generation trachyte. In the Tanguá and Morro de São João intrusive bodies, there is an intrusive phonolite with a similar geo-

\section{Pyroclastic dyke}

At the southern foot of the Morro dos Gatos hill, an outcrop of composite pyroclastic dyke is exposed (Loc. 4, Figure2). This dike is 40 to $80 \mathrm{~cm}$ wide, strikes northwest-southeast ward, and intrudes into the basement porphyritic granite. Different from the conventional dykes, the contact planes are not straight (Figure 3A), suggesting forceful intrusion of viscous trachyte magma.

The clasts of the pyroclastic rock are made up of angular fragments of trachyte with the size varying 1 to $6 \mathrm{~cm}$ (Figure 3B), classified to be lapilli. According to the digital photo analyses (Motoki et al., 2007e), the average contents of the clasts is about $30 \%$, which corresponds to clast matrix-supported texture. The matrix is completely consolidated.

There is fine-grained trachyte forming the intercalation between the pyroclastic dyke and the country granite along the contact. The intercalated trachyte is characterised by massive groundmass and it is constituted by small alkaline feldspar microliths and oxidised mafic minerals. The space between them shows a devitrified texture (Figure 3C). This aspect is very similar to those of the trachyte clasts (Figure 3D). Therefore, the trachyte clasts of the pyroclastic dyke are originated from
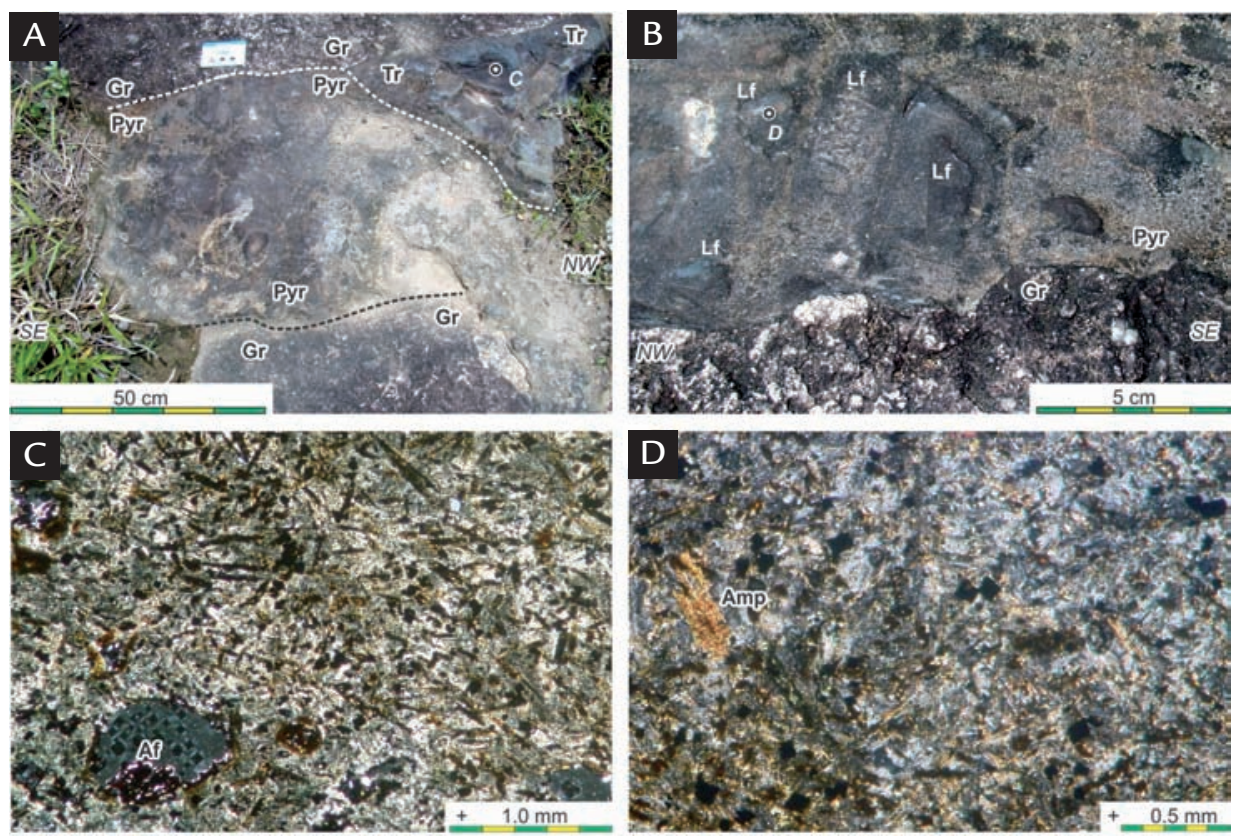

logic mode of occurrence (Motoki et al., 2010), called first generation phonolite. On the other hand, there are dykes of trachyte and phonolite intruding into the main body of the alkaline syenite and the nepheline syenite. These fine-grained

the intercalated second generation trachyte along the border.

The pyroclastic dykes with trachyte intercalation along the contact plane, similar to the above-mentioned example of the Morro dos Gatos, are also known in adjacent intrusive complexes, such as Mendanha (Motoki et al., 2007a) and Cabo Frio Island (Sichel et al., 2008) bodies. The intercalated trachyte of the Mendanha body is younger than the main alkaline syenite and nepheline syenite, and therefore, it is classified to be a member of the second generation trachyte or phonolite.

The matrix of the pyroclastic dyke is strongly consolidated. It can be attributed either to diagenesis or to pyroclastic welding. Considering the young age of the pyroclastic rock, from the Cretaceous to the early Cenozoic, the diagenesis model is improbable and the welding model is plausible. However, this rock shows no clear eutaxitic and rheo-eutaxitic textures, such as deformed essential lenses. In cases of extremely strong welding, the matrix transforms into hot glass mass with behaviour being similar to viscous lava, which the eutaxitic and rheo-eutaxitic textures become imperceptible (e.g. Motoki 1979). Examples of these rocks are commonly

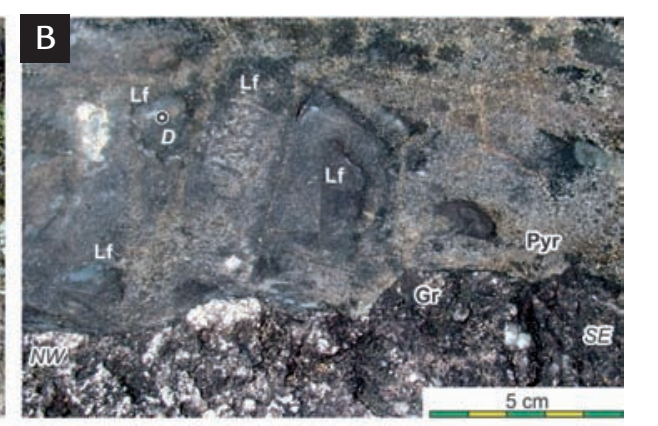

Figure 3

Pyroclastic dyke at the southern foot of the Morro dos Gatos hill, State of Rio de Janeiro, Brazil (Loc. 4, Figure 2):

A) Composite dyke of the welded pyroclastic rock and the second generation border trachyte that intruded into the country porphyritic granite of Silva Jardim.

B) Angular lithic fragments composed of fine-grained trachyte

C) Second generation trachyte collected form the point $C$ of the photo $A$

D) Trachyte fragment of the clast collected from the point $D$ of the photo $B$. Af - alkaline feldspar; Amp - amphibole; Pyr - pyroclastic dyke; Tr - trachyte ;

Gr - porphyritic granite; Lf - lithic fragment of trachyte. 
Figure 4

Evolution model of the pyroclastic eruption for the felsic alkaline intrusive complexes of Mendanha, Itaúna, and Cabo Frio Island after Motoki et al. (2008b): A) Forceful intrusion of trachyte dyke and lava dome formation.

B) Dome collapse, magma fluidization, and consequent pyroclastic flow eruption.

C) Vent collapse, conduit implosion, and high-grade welding and secondary flowage of the vent-filling pyroclastic materials.

The trachyte intercalation along the dyke contact corresponds to the consolidated part of the first stage. The trachyte intercalation of the pyroclastic dyke at the Loc. 4 suggests that a similar eruption took place at the Morro dos Gatos.

As a pyroclastic subvolcanic fis-

\section{Welded crystal tuff}

The welded crystal tuff is found as a boulder on the field of trachyte at the north-western border of the Morro dos Gatos intrusive body (Loc 5; Figure

Figure 5

Photomicrography of the crystal welded tuff of the Morro dos Gatos,

State of Rio de Janeiro, Brazil, collected from the Loc. 5 (Figure 2):

A) Small crystals fragments of the matrix. B) Idiomorphic alkaline feldspar aggregation.

C) Quartz polycrystalline fragment.

D) Lithic fragment of trachyte.

E) Large idiomorphic alkaline feldspar

phenocryst and small mineral fragments in crossed nicols.

F) The same scene in parallel nicols. Af - alkaline feldspar; Bi - biotite;

Cc - carbonates; $\mathrm{Hb}$ - hornblende;

$\mathrm{Q}$ - quartz; Li - lithic fragments.

A Intrusion

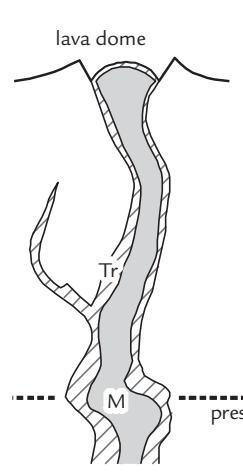

Tr: trachyte already consolidated M: magma

Vb: vent-filling pyroclastic material

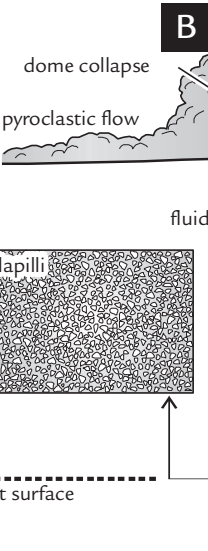

Fluidisation

Implosion

sure that would cause pyroclastic flow eruption, the pyroclastic dyke of the Loc. 4 seems to be too small. In case of the Mendanha body, the smallest pyroclastic dykes are $2 \mathrm{~m}$ wide and the largest dyke is more than $30 \mathrm{~m}$ wide (Motoki et al., 2007a). Therefore, the composite pyroclastic dyke of the Morro dos Gatos could be a branch of the main feeder. A welded tuff breccia dyke outcrop of the Mendanha body shows an example of the subvolcanic feeder branching, suggesting a possible mode for the occurrence of the pyroclastic dyke at the Loc. 4.
2). This rock has macroscopic aspects apparently similar to the first generation trachyte. However, under the microscope, a wide textural difference is observed (Figure 5).

This rock contains a large number of crystal fragments of alkaline feldspar, quartz, biotite, opaque minerals, and a
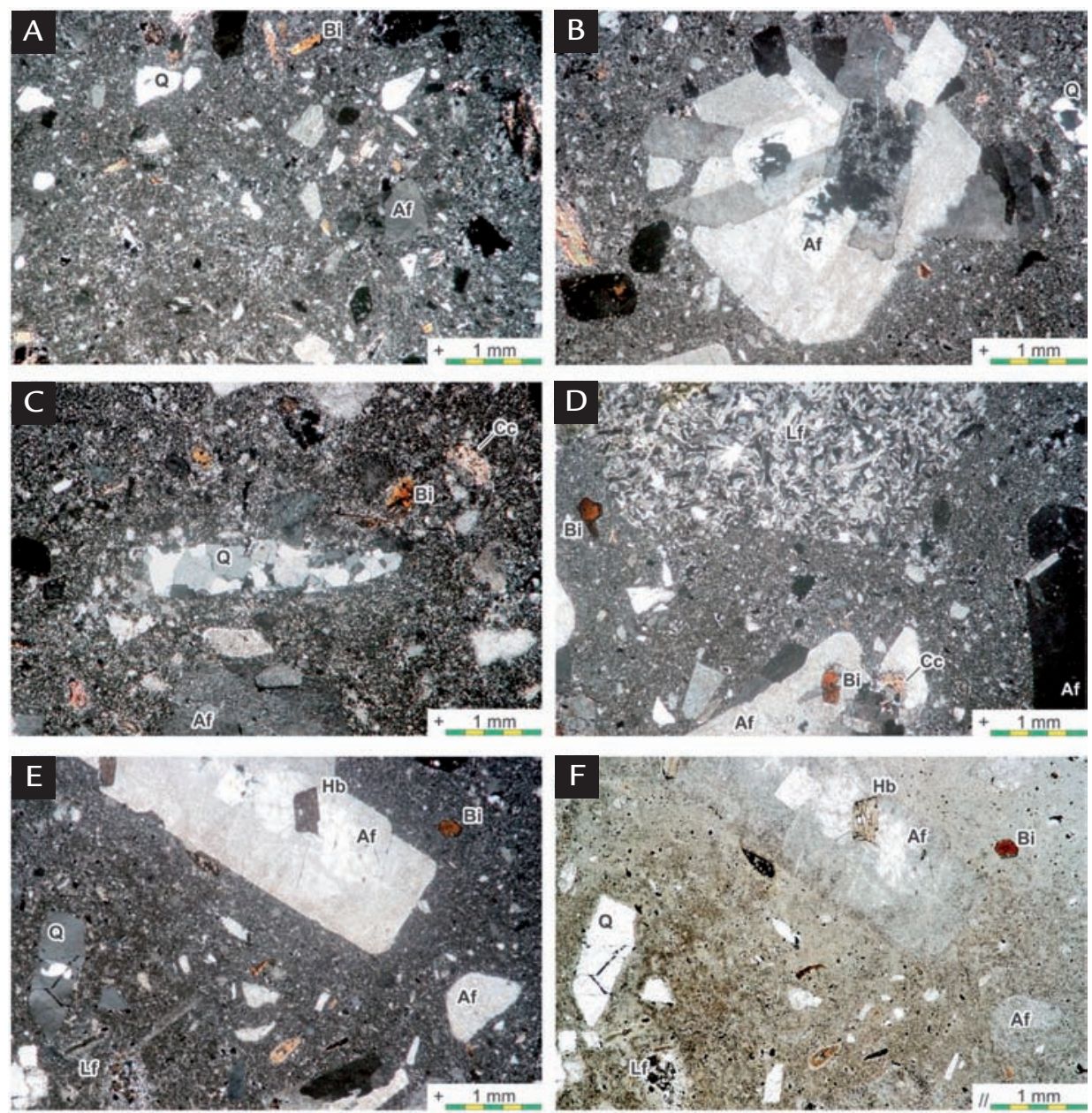
small amount of hornblende of the size varying from $0.005 \mathrm{~mm}$ to $0.6 \mathrm{~mm}$. Most of them have an angular shape with acute and sharp corners (Figure 5A). This texture, especially the wide variation in crystal size (Figure $5 \mathrm{~B}, \mathrm{E}$, $\mathrm{F})$, is characteristic of pyroclastic rocks (Motoki et al., 2007d; Novais et al., 2008). The size-frequency distribution diagram for the crystal fragments (Figure 6) shows a linear decrease in the logscale, which is characteristic of the fragments originated from an explosive activity. The fragments with the size of 100 to $150 \mu \mathrm{m}$ are deficient (Figure 6, arrow) suggesting the partial effect of volcanic gas sorting. According to the mineral fragment-rich composition and the small size of the mineral fragments,
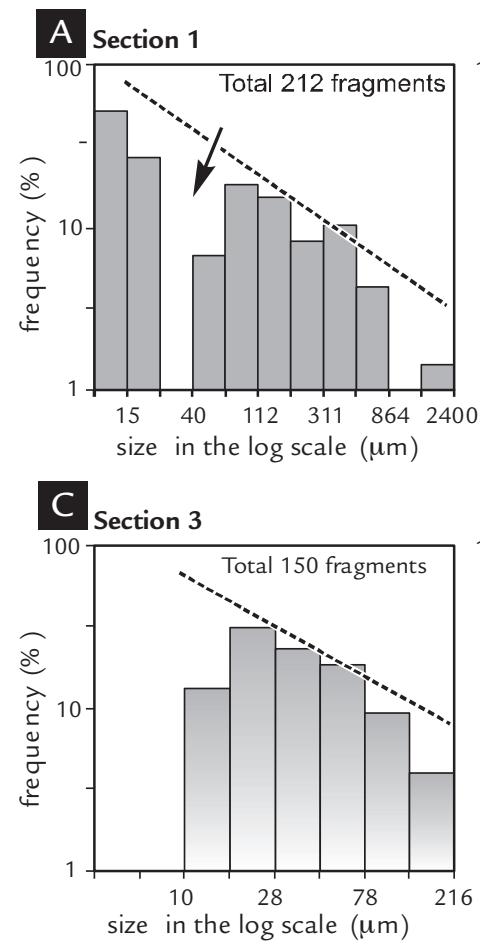

\section{What is the intrusive tuff?}

Generally welded tuff occurs as a widely distributed pyroclastic flow deposit covering a large area, from 1 to $1000 \mathrm{~km}^{2}$. Because of the extremely high fluidity of the pyroclastic emulsion, the lowlands along valleys and streams close to the source are filled by the pyroclastic flow deposit. When the deposit is densely welded, it is difficult to be eroded out. Although the pyroclastic deposits on the hills are eliminated, those on the lowlands can remain.

If the welded tuff of the Morro dos Gatos were of a pyroclastic flow deposit, the welded pyroclastic deposits must be present on the lowlands around this hill.
However, no pyroclastic rocks are found in the lowland. The occurrence area is extremely limited, like an outcrop, and a boulder exposed on the hill side or hill foot. This distribution is unfavourable for pyroclastic flow model, that is, extrusive tuff breccia model.

On the other hand, the limited distribution of pyroclastic rocks is known in cases of subvolcanic conduits and fissures. Some small subvolcanic fissures are called descriptively "pyroclastic dykes” (e.g. Motoki, 1979; Motoki \& Sichel, 2006). The examples are commonly found in the felsic alkaline intrusive complexes of the State of Rio de
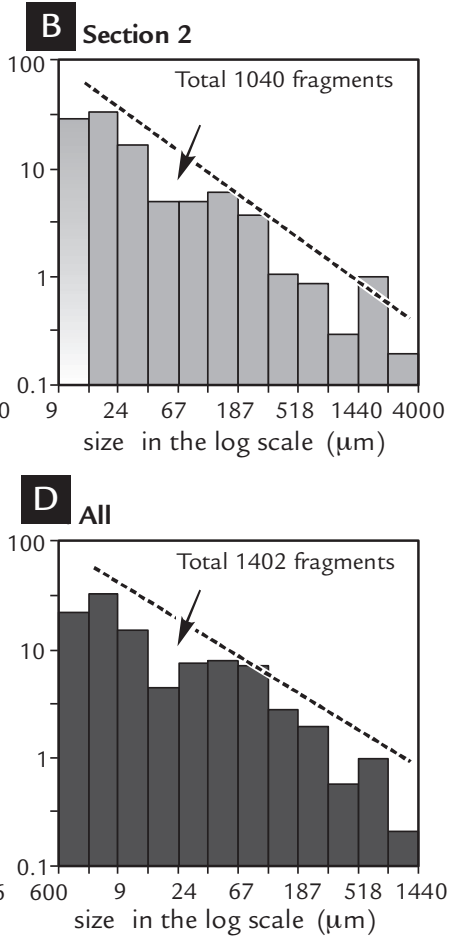

this rock is classified to be phenocrystrich crystal tuff, after Schmid (1981).

This crystal tuff is characterised also by large and idiomorphic alkaline feldspar phenocrysts of a $2 \mathrm{~mm}$ in general size and a maximum one of $6 \mathrm{~mm}$. Being similar to the first generation trachyte, most of them are of a crystal aggregate made up of tabular crystals of alkaline feldspar (Figure 5B). Individual alkaline feldspar has a highly tabular shape with a high aspect ratio, more than 6 , suggesting that they could be formed initially as sanidine. However, the small perthite texture is expressive and the transversal cooling fractures are not found. Therefore, they are orthoclase crystals, at least, during the magma cooling. The alkaline feldspar contains many idiomorphic

Figure 6

Size-frequency distribution diagram for the crystal fragments of the welded crystal tuff collected from the Loc. 5 (Figure 2), of the Morro dos Gatos alkaline rock body, State of Rio de Janeiro, Brazil. mineral inclusions of alkaline feldspar, biotite, hornblende, and opaque minerals (Figure 5E, F).

Biotite and hornblende phenocrysts are present. The biotite is partially transformed into vermiculite. The presence of poly-crystal quartz fragments is remarkable (Figure 5C, E, F). The quartz is probably originated from the basement of Silva Jardim Granite. There are lithic fragments of trachyte and granite with general sizes of $2 \mathrm{~mm}$ to $3 \mathrm{~mm}$ (Figure 5D, E, F). Their maximum size is about $5 \mathrm{~mm}$. The abovementioned observations indicate that the wall rocks of this pyroclastic conduit are granite and first generation trachyte. The pyroclastic eruption took place at the last phase of the alkaline magmatism of the Morro dos Gatos.
Janeiro (Motoki et al., 2007b; 2008b). The fission track datings for apatite of the basement rock of the State of Rio de Janeiro show that the Earth's surface of the Cretaceous to early Cenozoic was about $3000 \mathrm{~m}$ higher than the present one (Motoki et al., 2007b).

The welded tuff of the Morro dos Gatos is considered to be constituent of a small subvolcanic fissure or conduit, that is, intrusive pyroclastic rock bodies. No surface deposit, such as of pyroclastic flow, pyroclastic fall, and epiclastic breccia are present. Therefore, the Morro dos Gatos is not an extinct volcano (Figure 7). 
Figure 7

Schematic illustration for the geologic emplacement of the intrusive welded crystal tuff and lapilli tuff of the Morro dos Gatos, State of Rio de Janeiro Brazil as a subvolcanic pyroclastic conduit and fissure, showing the relation between the present exposure and the volcanic edifice of the eruption time which is Cretaceous to early Cenozoic. The cross section line $A-A^{\prime}$ is shown on the Figure 2.

\section{Genesis of the crystal tuff}

Crystal tuff is found generally as constituent of pyroclastic fall and pyroclastic flow (e.g. Dennison \& Textoris, 1970; Boles \& Coombs, 1975; Niem, 1977; Barr et al., 1990; Jiang et al., 2005). They are not abundant and almost all of the vent-filling pyroclastic rocks, called vent breccia (MacDonald, 1972), are composed of lithic clast-rich welded tuff breccia (Motoki et al., 2008b).

In the Sumiyoshigawa acidic rock body, Kobe, Japan, there is an example of vent-filling phenocryst-rich crystal welded tuff of rhyolitic composition of the Cretaceous (Figure 8). Based on the field observation and petrographic description, Motoki (1979) proposed the eruption model in three stages: 1) Explosive pyroclastic eruptions; 2) Effusive pyroclastic eruptions; 3) Welding of the vent-filling pyroclastic materials. Crystal tuff was formed in the second stage.

The explosive eruption of the first stage opened a new vent and crater. The volcanic explosion was not constant but interruptive, and the speed of the volcanic gas ascending in the conduit was widely variable. The eruption column was high and the pyroclastic materials deposited on the surface were relatively cold. Such eruptions resulted in unsorted volcanic breccia, lapilli and tuff breccia, which are commonly found in vent-filling pyroclastic materials.

After the opening of the crater and

\section{Conclusion}

The above-mentioned field observations, lithologic descriptions, and petrographic studies of the composite pyroclastic dyke and welded crystal present the following conclusions.

1. The Morro dos Gatos alkaline body its enlargement, the eruption became more constant and effusive. The volcanic gas ascending in the conduit became constant. Because of the funnel-shaped conduit, the volcanic gas was rapid in deep sites and slow in shallow ones. Therefore, boulders were concentrated in deep sites forming clast-supported agglomerates, whole lapilli formed in the middle sites resulting in clast matrix-supported lapilli tuff. The small tuff-size clasts and crystals were concentrated in shallow sites, forming crystal tuff. The glass-shards were carried out of the crater. The eruption column was low, the surface pyroclastic deposits were hot, and the pyroclastic flow deposit was densely welded. In the conduit, vent-filling welded crystal tuff was formed.

In comparison with pyroclastic flow deposits of the Earth's surface, vent-filling subvolcanic pyroclastic materials are of slow cooling. The thickness is virtually infinite. Therefore, an extremely strong welding can take place. The matrix transforms into hot glass mass which has the same mechanical properties of ventfilling lava. The vent wall is sub-vertical and strong secondary flowage takes place. Because of the ultra-high grade welding and secondary flowage, eutaxitic textures become imperceptible.

The sample shown on the Figure $8 \mathrm{~B}$ is a drilling core and shows highly flattened essential lenses. For extrusive welded tuffs, this texture corresponds to very high-grade welding. However, the welding grade of vent-filling intrusive tuff breccia is much higher, and this texture is considered to be of relatively low-grade. After the cooling, the pyroclastic rock was consolidated and its physical firmness becomes the same or higher than that of rhyolite lava.

A similar eruption mode is observed in the Kumano acidic rock body (Aramaki, 1965; Miura, 1999) and the Osuzuyama one (Nakada, 1983), Japan. In spite of the geochemical differences, the pyroclastic materials of phonolitic or trachytic composition have physical behaviours similar to those of rhyolitic and dacitic. The unusually strong welding and secondary flowage of vent filling pyroclastic rocks are also found in the felsic alkaline complexes of the State of Rio de Janeiro (Motoki \& Sichel, 2006; Motoki et al., 2007a; b; 2008b).

The welded crystal tuff of the Morro dos Gatos is characterised by idiomorphic phenocrysts. The lithic fragments are rare and small (Figure 5) and the texture is quite similar to that of the crystal tuff of the Sumiyoshigawa acidic rock body. Therefore, the welded crystal tuff of the Morro dos Gatos could have been formed by a similar process. The idiomorphic crystals suggest that the eruption was not so much explosive as relatively effusive. is a small intrusion with the extension of $1.2 \times 0.8 \mathrm{~km}$ occupying an area of $0.5 \mathrm{~km}^{2}$. It is composed mainly of monzonite (field name) and trachyte. The monzonite is projected on the limit between syenite and monzonite of the
IUGS classification nomenclature.

2. There is a pyroclastic dyke and a welded crystal tuff. They are of extremely limited distribution, indicating that they are not constituent of pyroclastic flow deposits, but of vent-filling intrusive 

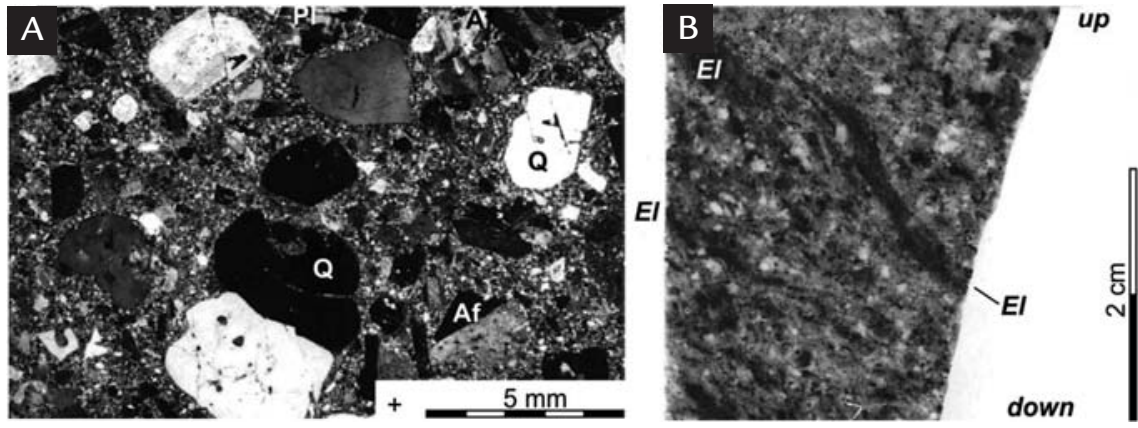

pyroclastic bodies, such as subvolcanic conduit, subvolcanic fissure, and pyroclastic dyke.

3. A composite pyroclastic dyke, $40 \mathrm{~cm}$ to $80 \mathrm{~cm}$ wide, is found at the south foot of the hill. It is intrusive into the basement granite and constituted by welded tuff breccia with abundant lapilli-size angular trachyte fragments. Along the contact plane, second generation trachyte is intercalated between the tuff breccia and host granite.

\section{Acknowledgement}

The authors are grateful to the FAPERJ, Carlos Chagas Filho Foundation, of the Rio de Janeiro State Government, for the financial support of the category
4. The welded crystal tuff is characterised by phenocrysts of alkaline feldspar and biotite, showing a crystal matrixsupported texture. The phenocrysts are idiomorphic and $2 \mathrm{~mm}$ in general size. Many phenocrysts are aggregations made up mainly of euhedral alkaline feldspar crystals.

5. The matrix of the crystal tuff is composed of mineral fragments less than $1 \mathrm{~mm}$. The size-frequency diagram for the mineral fragments suggests that

APQ1 entitled "Petrologia, geoquímica e magmagêneses dos corpos alcalinos da Ilha de Cabo Frio e Morro de São João e seus aspectos ambientais como pat-
Figure 8

Vent-filling phenocryst-rich intrusive welded crystal tuff of the Sumiyoshigawa acidic complex rock body, Kobe, Japan, after Motoki (1979):

A) Photomicrography;

B) Macroscopic photo of a drilling core. Q - quartz; Af - alkaline feldspar; Lf - lithic fragment; El - essential lens.

they are originated from an explosive eruption. The matrix is strongly welded and completely devitrified. The eutaxitic and rheo-eutaxitic textures have been lost because of the unusually high-grade welding.

6 . The phenocrysts concentration in the volcanic conduit took place by the sorting of volcanic gas that was in ascension in the volcanic vent during the continuous and effusive eruptive phase.

rimônios geológicos”. The authors thank to geologist Rodrigo Soares of the Federal Fluminense University for the opportunity of the present collaborative research.

\section{Reference}

ALVES, A.P., GERALDES, M.C., VALENTE, S. Aplicação de mapeamento de elementos em MEV nos feldspatos de rochas alcalinas: identificação de magmatismo bimodal ( $\mathrm{Na}$ e $\mathrm{Ca}$ ) no Maciço do Mendanha (RJ). Geochimica Brasiliensis, São Paulo, 2011. (in press).

ARAMAKI, S. Mode of emplacement of acid igneous complex (Kumano Acidic Rocks) in southeastern Kii Peninsula. Journal of Geological Society of Japan, Tokyo, v. 71, p. 525-540, 1965.

BARR, S.M., TANTISUKRIT, C., YAOWANOIYOTHIN, W., MACDONALD, A. Petrology and tectonic implications of Upper Paleozoic volcanic rocks of the Chiang Mai belt, northern Thailand. Journal of Southeast Asian Earth Sciences, v. 4, n. 1, p. 37-47, 1990.

BOLES, J.R., COOMBS, D.S. Mineral Reactions in Zeolitic Triassic Tuff, Hokonui Hills, New Zealand. Geological Society of America Bulletin, v. 86, n. 2, p. 163-173, 1975.

BROTZU, P., BECCALUVA, L., CONTE, A., FONSECA, M., GARBARINO, C., GOMES, C.B., LEONG, R., MACCIOTTA, G., MANSUR, R.L., MELLUSO, L., MORBIDELLI, L., RUBERTI, E., SIGOLO, J.B., TRAVERSA, G., VALENÇA, J.G. Petrological and geochemical studies of alkaline rocks from continental Brazil. The syenitic intrusion of Morro Redondo, RJ. Geochimica Brasiliensis, São Paulo, v. 3, p. 63-80, 1989.

BROTZU, P., GOMES, C. B., MELlUSO, L., MORBIDELlI, L., MORRA, V., RUBERTI, E. Petrogenesis of coexisting $\mathrm{SiO}_{2}$-undersaturated to $\mathrm{SiO}_{2}$-oversaturated felsic igneous rocks: the alkaline complex of Itatiaia, southern eastern Brazil. Lithos, v. 40, p. 133-156, 1997.

BROTZU, P., MELlUSO, L., BENNIO, L., GOMES, C.B., LUSTRINO, M., MORBIDELLI, L., MORRA, V., RUBERTI, E., TASSINARI, C., D'ANTONIO, M. Petrogenesis of the Early Cenozoic potassic alkaline complex of Morro de São João, southeastern Brazil. Journal of South American Earth Sciences, v. 24, p. 93 115, 2007. 
DENNISON, J.M., TEXTORIS, D.A. Devonian tioga tuff in Northeastern United States. Bulletin of Volcanology, v. 34, n. 1, p. 289-294, 1970.

DERBY, O.A. On nepheline-rocks in Brazil - part II. The Tinguá Mass. The Quarterly Journal of the Geological Society of London, v. 47, p. 251-265, 1897

EKREN, E.B., BYERS, F.M. Ash-flow fissure vent in west-central Nevada. Geology, v. 4, n. 4, p. 247-251, 1976.

GERALDES, M.C., NETTO, A.M. A.ALMEIDA, J.C.H., ALVES, A.P.R. E MOTA, C.E.M. Feições vulcanogênicas no Maciço Alcalino do Mendanha (RJ): modelos geodinâmicos e implicações na evolução do paleorrelevo onshore da bacia de Santos no Cretáceo. Boletim de Geociências da Petrobras, Rio de Janeiro, 2011. (in press).

GUEDES, E., HELIBRON, M., VASCONCELOS, P.M., VALERIANO, C.M., ALMEIDA, J.C.H., TEIXEIRA, W., THOMÁZ FILHO, A. K-Ar and ${ }^{40} \mathrm{Ar} /{ }^{39} \mathrm{Ar}$ ages of dykes emplaced in the on-shore basement of the Santos Basin, Resende area, SE. Brazil: implications for the south Atlantic opening and Tertiary reactivation. Journal of South American Earth Sciences, v. 18, p. 371-182, 2005.

HEILBRON, M., MACHADO, N. Timing of terrane accretion in the NeoproterozoicEopaleozoic Ribeira orogen (se Brazil). Precambrian Research, v. 125, p. 87-112, 2003.

HEILBRON, M., MOHRIAK, W., VALERIANO, C.M., MILANI, E., ALMEIDA, J.C.A., TUPINAMBÁ, M. From collision to extension: the roots of the southeastern continental margin of Brazil. Geophysical Monograph, American Geophysical Union, v. 115, p. 1-32, 2000.

JIANG, Y.H., LING, H.F., JIANG, S.Y., FAN, H.H., SHEN, W.Z., NI, P. Petrogenesis of a Late Jurassic Peraluminous Volcanic Complex and its High-Mg, Potassic, Quenched Enclaves at Xiangshan, Southeast China. Journal of Petrology, v. 46, n. 6, p. 1121-1154, 2005.

KANO, K., MATUURA, H., YAMAUCH, S. Miocene rhyolitic welded tuff infilling a funnel-shaped eruption conduit Shiotani, southeast of Matsue, SW Japan. Bulletin of Volcanology, v. 59, n. 2, p. 125-135, 1996.

MACDONALD, G.A. Volcanoes. Prentice-Hall, Englewood Cliffs, 1972.510 p.

MARTINS C.R., BORGHI G. Morro dos Gatos, foco de rochas alcalinas. Silva Jardim - RJ. Mineração Metalurgia. Rio de Janeiro, v. 46, p. 18-20, 1982.

MIURA, D. Arcuate pyroclastic conduits, ring faults, and coherent floor at Kumano caldera, southwest Honshu, Japan. Journal of Volcanology and Geothermal Research, v. 92, n. 3-4, p. 271-294, 1999.

MORAES, J.M. Geologia do granito Silva Jardim (RJ). Implicações na evolução tectônica dos terrenos oriental e Cabo Frio. Rio de Janeiro, Brazil: Faculty of Geology of Rio de Janeiro State University, 2009. 68 p. (Master Thesis).

MOTA, C.E.M., GERALDES, M.C. A classificação de brechas magmáticas e sua implicação na evolução do Complexo Alcalino de Nova Iguaçu-RJ. Geociências, Rio Claro, v. 25, p. 37-48, 2006.

MOTA, C.E.M., GERALDES, M.C., ALMEIDA, J.C.H., VARGAS, T., SOUZA, D.M., LOUREIRO, R.O., SILVA, A.P. Características isotópicas ( $\mathrm{Nd}$ e Sr), geoquímicas e petrográficas da intrusão alcalina do Morro de São João: implicações geodinâmicas e sobre a composição do Manto Sublitosférico. Revista do Instituto de Geociências - USP, Série Científica, São Paulo, v. 9, n. 1, p. 85-100, 2009.

MOTOKI, A. Cretaceous volcanic vents in southeast part of Mt. Rokko, western Honshu, Japan. Bulletin of the Volcanological Society of Japan, Tokyo, v. 24, n.2, p. 55-72, 1979.

MOTOKI, A., SICHEL, S.E. Avaliação de aspectos texturais e estruturais de corpos vulcânicos e subvulcânicos e sua relação com o ambiente de cristalização, com base em exemplos do Brasil, Argentina e Chile. REM-Revista Escola de Minas, Ouro Preto, v. 59, n. 1, p. 13-23, 2006.

MOTOKI, A., SICHEL, S.E. Hydraulic fracturing as a possible mechanism of dykesill transitions and horizontal discordant intrusions in trachytic tabular bodies of Arraial do Cabo, State of Rio de Janeiro, Brazil. Geofísica Internacional, México, v. 47, v. 1, p. 13-25, 2008.

MOTOKI, A., NEVES, J.L.P., VARGAS, T. Quantitative colour analyses using digital specification technique for Mármore Bege Bahia, a representative Brazilian ornamental limestone of breccia-like texture. REM-Revista Escola de Minas. Ouro Preto, v. 58, n. 2, p. 113-120, 2005. 
MOTOKI, A., ZUCCO, L.L., SICHEL, S.E., AIRES, J.R., PETRAKIS, G.H. Development of the tecnique for digital colour specification and the new nomenclatures of ornamental rock based on the measured colours. Geociencias, Rio Claro, v. 25, n. 4, p. 403-415, 2006.

MOTOKI, A., SOARES, R., NETTO, A.M., SICHEL, S.E., AIRES, J.R., LOBATO, M. Geologic occurrence shape of pyroclastic rock dykes in the Dona Eugênia River Valley, Municipal Park of Nova Iguaçu, Rio de Janeiro. Geociências, Rio Claro, v. 26, n. 1, p. 67-82. 2007a.

MOTOKI, A., SOARES, R., NETTO, A.M., SICHEL, S.E., AIRES, J.R., LOBATO, M. Genetic reconsideration of the Nova Iguaçu Volcano model, State of Rio de Janeiro, Brazil: eruptive origin or subvolcanic intrusion? REM-Revista Escola de Minas, Ouro Preto, v. 60, n. 4, p. 583-592. 2007b.

MOTOKI, A., SOARES, R., LOBATO, M., SICHEL, S.E., AIRES, J.R. Weathering fabrics in felsic alkaline rocks of Nova Iguaçu, State of Rio de Janeiro, Brazil. REM-Revista Escola de Minas, Ouro Preto, v. 60, n. 3, p. 451-458, 2007 c.

MOTOKI, A., NOVAIS, L.C.C., SICHEL, S.E., NEVES, J.L., AIRES, J.R. Felsic pyroclastic rock originated from subaqueous eruption in the Espírito Santo sedimentary basin: an association with the tectonic-sedimentary model. Geociências, Rio Claro, v. 26, n. 2, 151-160, 2007 d.

MOTOKI, A., PETRAKIS, G.H., SOARES, R., SICHEL, S.E., AIRES, J.R. 2007. New method of semi-automatic modal analyses for phenocrysts of porphyritic rocks based on quantitative digital colour specification technique. REM-Revista Escola de Minas, Ouro Preto, v. 60, n. 1, p. 13-20, 2007 e.

MOTOKI, A., SICHEL, S.E., SOARES, R.S., NEVES, J.L.P., AIRES, J.R. Geological, lithological, and petrographical characteristics of the Itaúna Alkaline Intrusive Complex, São Gonçalo, State of Rio de Janeiro, Brazil, with special attention of its emplace mode. Geociências, Rio Claro, v. 27, n. 1, p. 33-44, 2008 a.

MOTOKI, A., SICHEL, S.E., SOARES, R.S., AIRES, J.R., SAVI, D.C., PETRAKIS, G.H., MOTOKI, K.F. Vent-filling pyroclastic rocks of the Mendanha, the Itaúna, and the Cabo Frio Island, State of Rio de Janeiro, Brazil, and their formation process based of the conduit implosion model. Geociências, Rio Claro. v. 27, n. 3, p. 451-467, 2008b.

MOTOKI, A., SICHEL, S.E., SAVI, D.C., AIRES, J.R. Intrusion mechanism of tabular intrusive bodies of subhorizontal discordant emplacement of the Cabo Frio island and neighbour areas, State of Rio de Janeiro, Brazil. Geociências, Rio Claro, v. 27, n. 2, p. 207-218, 2008c.

MOTOKI, A., PETRAKIS, G.H., SICHEL, S.E., CARDOSO, C.E., MELO, R.C., SOARES, R.S., MOTOKI, K.F. Landform origin of the Mendanha Massif, State of Rio de Janeiro, Brazil, based on the geomorphological analyses by summit level map technique. Geociências, Rio Claro, v. 27, n. 1, p. 99-115, 2008 d.

MOTOKI, A., SICHEL, S.E., PETRAKIS, G.H. Genesis of the tabular xenoliths along contact plane of the mafic dykes of cabo frio area, state of Rio de Janeiro, Brazil: Thermal delamination or hydraulic shear fracturing? Geociências, Rio Claro, v. 28, n. 1, p. 15-26, 2009a.

MOTOKI, A., SICHEL, S.E., CAMPOS, T.F.C., SRIVASTAVA, N.K., SOARES, R.S. Present-day uplift rate of the Saint Peter and Saint Paul Islets, Equatorial Atlantic Ocean. REM-Revista Escola de Minas, Ouro Preto, v. 62, n. 3, p. 331-342, 2009b.

MOTOKI, A., SICHEL , S.E., VARGAS, T., AIRES, J.R., IWANUCH, W., MELLO, S.L.M., MOTOKI, K.F., SILVA, S., BALMANT, A., GONÇALVES, J. Geochemical evolution of the felsic alkaline rocks of Tanguá, Rio Bonito, and Itaúna intrusive bodies, State of Rio de Janeiro, Brazil. Geociências, Rio Claro, v.29, n. 3, p. 291-310, 2010.

MOTOKI, A., VARGAS, T., IWANUCH, W., SICHEL, S.E., BALMANT, A., AIRES, J.R. Tectonic breccia of the Cabo Frio area, State of Rio de Janeiro, Brazil, intruded by Early Cretaceous mafic dyke: Evidence of the Pan-African brittle tectonism? REM-Revista Escola de Minas, Ouro Preto, v. 64, n. 1., p. 25-36, 2011.

NAKADA, S. Zoned Magma Chamber of the Osuzuyama Acid Rocks, Southwest Japan. Journal of Petrology, v. 24, n.4, p. 471-494, 1983.

NIEM, A.R. Mississippian pyroclastic flow and ash-fall deposits in the deep-marine Ouachita flysch basin, Oklahoma and Arkansas. Geological Society of America Bulletin, v. 88, n. 1, p. 49-61, 1977. 
NOVAIS, L. C. C., ZALENKA, T., SZATMARI, P., MOTOKI, A., AIRES, J. R., TAGLIARI, C. V. Occurence of ignimbrite volcanics in the northern Espírito Santo Basin, Brazil: An advance in the model of tectonic-sedimentary evolution of the basin: An advance in the model of tectonic-sedimentary evolution of the basin. Boletim de Geociências da Petrobras, Rio de Janeiro, v. 16, n. 1, p. 139-156, 2008.

PETRAKIS, G. H., MOTOKI, A., SICHEL, S. E., ZUCCO, L. L., AIRES, J. R., MELLO S. L. M. Ore geology of special quality gravel and artificial sand: exemples of alkaline syenite of Nova Iguaçu, State of Rio de Janeiro, and rhyolite of Nova Prata, State of Rio Grande do Sul, Brazil. Geociências, Rio Claro, v. 29, n.1, p.2132, 2010.

REEDMAN, A. J., PARK, KI HWA, MERRIMAN, R. J., KIM, S. E. Welded tuff infilling a volcanic vent at Weolseong, Republic of Korea. Bulletin of Volcanology, v. 49, n. 3, p. 541-546, 1987.

RICCOMINI, C., SANT'ANNA, L. G., FERRARI, A. L. Evolução geológica do rift continental do Sudeste do Brasil. In: MANTESSO-NETO, V., BARTORELLI, A., CARNEIRO, C. D. R., BRITO-NEVES, B. B. Ed. Geologia do Continente SulAmericno: Evolução da obra de Fernando Flávio Marques de Almeida. São Paulo. Editora Beca, p. 385-405, 2004.

SCHMID, R. Descriptive nomenclature and classification of pyroclastic deposits and fragments - Recommendations of the IUGS Subcommission on the Systematics of Igneous Rock. Earth and Evironmental Science, v. 70, n. 2, p. 794-799, 1981.

SICHEL, S. E., MOTOKI, A., SAVI, D. C., SOARES, R. S. Subvolcanic vent-filling welded tuff breccia of the Cabo Frio Island, State of Rio de Janeiro, Brazil. REMRevista Escola de Minas, Ouro Preto, v. 61, n. 4, p. 423-432, 2008.

SILVA, L.C., SANTOS, R.A., DELGADO, I.M., CUHA, H.C.S. Mapa Geológico do Estado do Rio de Janeiro, escala 1:250.000. Serviço Geológico do Brasil, CPRM, Rio de Janeiro, 2000.

SILVA, S. Interpretação morfológica baseada nas técnicas de seppômene sekkokumen dos maciços alcalinos do Estado do Rio de Janeiro. Instituto de Geociências da Universidade Federal Fluminense, 2010. 123p. (Máster Thesis, unpublished).

SMITH, R. L. Ash flows. Geological Society of America Bulletin. v. 71, p. 795-842, 1960.

STRECKEISEN, A. L. Plutonic rocks - classification and nomenclature recommended by the IUGS Subcommission on the Systematics of Igneous Rocks: Geotimes, v. 18, n. 10, p. 26-30. 1973.

VASCONCELLOS, E. M. G., GOMES, C. B. Caracterização petrográfica de brechas vulcânicas no Complexo Alcalino de Tunas, PR. Revista Brasileira de Geociências, São Paulo, v. 22, n. 3, p. 269-274, 1992.

WOLFF, J. A., ELLWOOD, B. B, SACHS, S. D. Anisotropy of magnetic susceptibility in welded tuffs: application to a welded-tuff dyke in the tertiary Trans-Pecos Texas volcanic province, USA. Bulletin of Volcanology, v. 51, n. 4, p. 299-310, 1999.

Artigo recebido em 31 de janeiro de 2011 e aprovado em 29 de abril de 2011. 